\title{
Perchlorate, Thiocyanate, and Nitrate in Edible Cole Crops (Brassica sp.) Produced in the Lower Colorado River Region
}

\author{
C. A. Sanchez $\cdot$ B. C. Blount $\cdot$ L. Valentin-Blasini $\cdot$ \\ R. I. Krieger
}

Received: 9 July 2007/ Accepted: 2 October 2007/Published online: 26 October 2007

(C) Springer Science+Business Media, LLC 2007

\begin{abstract}
The Colorado River is contaminated with low levels of perchlorate. Perchlorate has the potential to disrupt thyroid function by inhibiting the uptake of iodide. Brassica are rich sources of thiocyanate and nitrate, also inhibitors of iodide uptake. This study was conducted to estimate potential human exposure to perchlorate, thiocyanate, and nitrate from Brassica sp. irrigated with Colorado River water. Results indicate that Brassica sp. irrigated with Colorado River water do accumulate trace levels of perchlorate. However, the levels of perchlorate observed are low relative to the nitrate and thiocyanate naturally present in these species and low relative to the reference dose recommended by the NAS and the USEPA.
\end{abstract}

Keywords Perchlorate exposure - Thiocyanate .

Nitrate $\cdot$ Thyroid $\cdot$ Goitrogens

Perchlorate has the potential to cause thyroid dysfunction by inhibiting iodide uptake by the sodium iodide symporter (NIS) (Clark 2000). There is concern that perchloratecontaminated waters may represent a health risk as sources

C. A. Sanchez $(\bowtie)$

Department of Soil, Water, and Environmental Sciences,

Yuma Agricultural Center, The University of Arizona,

Yuma, AZ 85364, USA

e-mail: Sanchez@ag.arizona.edu

B. C. Blount · L. Valentin-Blasini

National Center for Environmental Health, Centers for Disease

Control and Prevention (CDC), Atlanta, GA 30341, USA

\section{R. I. Krieger}

Personal Chemical Exposure Program, Department of Entomology, University of California, Riverside,

CA 92521, USA of drinking water to humans and irrigation water to food crops. However, a number of other inorganic anions present in some food crops, including nitrate and thiocyanate, can act as goitrogens by blocking iodide uptake of the NIS in a competitive manner (Wyngaarden et al. 1953; Tonacchera et al. 2005).

Perchlorate in the lower Colorado River has ranged from 2 to $9 \mu \mathrm{g} / \mathrm{L}$ and was introduced into Lake Mead through contamination from a perchlorate salt manufacturing plant near the Las Vegas Wash (DHS 2000). The production of fresh market vegetables in the lower Colorado regions of Arizona and California is a 2 billion dollar industry. This industry relies on Colorado River water for irrigation and there is concern that consumption of perchlorate through food produced in the region may represent a significant source of exposure. Several plant species have been shown to absorb perchlorate from soil and irrigation water (Tan et al. 2004; Yu et al. 2004) and there is evidence that perchlorate accumulates in certain food crops in general (Jackson et al. 2005; Sanchez et al. 2005a), and in the lower Colorado River region in particular (Sanchez et al. 2005b, 2006). However, thiocyanates and nitrate are also present in Brassica sp. (Kushad et al. 1999). The objectives of this project was to estimate potential human exposure to perchlorate from broccoli (Brassica oleracea L., var italica), cauliflower (B. oleracea L., var. botrytis), and cabbage (B. oleracea L., var. capitata) produced in the lower Colorado River region, and estimate the possible biologic significance of perchlorate relative to thiocyanate and nitrate in these edible crops.

\section{Materials and Methods}

All fields selected for sampling were irrigated with water from the Colorado River. Areas sampled included the 
Coachella Valley and Imperial Valley of California and the Lower Colorado River Valley of California and Arizona. Samples were collected during production seasons from 2003 to 2005. Edible portions were diced, mixed thoroughly, and a sub-sample was placed in a freezer. The frozen samples were freeze-dried as space became available on a freeze drier and weights recorded before and after freeze-drying. The samples were ground and stored in vials for extraction.

We used an extraction procedure where $600 \mathrm{mg}$ of freeze-dried product was weighed into centrifuge tubes, $15 \mathrm{~mL}$ of DI water were added, the tubes were boiled for $30 \mathrm{~min}$, and the contents were placed in a refrigerator overnight with occasional gentle shaking (Ellington and Evans 2000). The tubes were then centrifuged for $30 \mathrm{~min}$ and the supernatants filtered through $0.2 \mu \mathrm{m}$ Gel-man ion membrane syringe filters. Two milliliters of the above extract (extract one) was reacted with $1,000 \mathrm{mg}$ DD-alumina. Vials were gently agitated two or three times over a 24-h period. Eighteen milliliters of DI water were then added to this mixture. After stirring and settling, this solution was filtered through another $0.2 \mu \mathrm{m}$ Gel-man ion membrane syringe filter and the resulting solution was labeled "extract 2".

This sample was stored in the freezer until analysis for perchlorate and thiocyanate by ion chromatography/tandem mass spectroscopy (IC/MS/MS) using stable isotope labeled internal standard methodology reported previously (Valentin-Blasini et al. 2005). Briefly, $0.5 \mathrm{~mL}$ of aqueous sample extract was spiked with an isotopically labeled internal standards $\left(\mathrm{Cl}^{18} \mathrm{O}_{4}^{-}, \mathrm{SC}^{15} \mathrm{~N}^{-}\right)$and diluted 1:1 with deionized water. This solution was subsequently analyzed using ion chromatography-electrospray ionization-tandem mass spectrometry. Perchlorate and thiocyanate were quantified based on the peak area ratio of analyte to stable isotope-labeled internal standard. A subset of samples $(10 \%)$ were analyzed further using standard addition, and produced acceptable percent differences of $<10 \%$. Absolute assay accuracy was verified by the blind analysis of four different reference solutions containing perchlorate and thiocyanate (AccuStandard, New Haven, CT, USA); analysis of these proficiency testing solutions across the study time period yielded an average percent difference of $\pm 5.2 \%$. The perchlorate MDL was estimated to be $0.02 \mu \mathrm{g} /$ $\mathrm{L}$ and the MRL was $0.1 \mu \mathrm{g} / \mathrm{L}$. The percentage dry matter of the edible portions of broccoli, cauliflower, and cabbage were $13 \%, 9 \%$, and $9 \%$, respectively. Therefore, an MRL of $0.1 \mu \mathrm{g} / \mathrm{L}$ by IC/MS/MS would correspond to approximately $2-3 \mu \mathrm{g} / \mathrm{kg}$ fw. We used median perchlorate and thiocyanate concentrations in the edible crops and mean and 90th percentile consumption estimates to estimate exposures. The data for broccoli and cabbage were taken from Smiciklas-Wright et al. (2002) and the data for cauliflower were unpublished data provided to the authors by Exponent.

Nitrate in freeze-dried plant tissue was determined potentiometrically (Baker and Smith 1969). Approximately $400 \mathrm{mg}$ of tissue and $0.04 \mathrm{~L}$ of $\mathrm{Al}_{2}\left(\mathrm{SO}_{4}\right)_{3}$ buffer solution were placed in $250 \mathrm{~mL}$ Erlenmeyer flasks, put on a shaker for $30 \mathrm{~min}$ and filtered. The filtrates were analyzed for nitrate using a calibrated nitrate selective electrode and potentiometer.

\section{Results and Discussion}

Perchlorate concentrations in the irrigation water ranged from 2 to $9 \mu \mathrm{g} / \mathrm{L}$ during the sampling period (Sanchez et al. 2005b, 2006). Levels of perchlorate in edible plant material ranged from 3.5 to $106.9 \mu \mathrm{g} / \mathrm{kg}$ fw, $4.2-40.7 \mu \mathrm{g} / \mathrm{kg}$ fw, and $4.6-63.2 \mu \mathrm{g} / \mathrm{kg} \mathrm{fw}$ in broccoli, cauliflower, and cabbage, respectively (Table 1). Perchlorate, thiocyanate and nitrate concentrations were significantly higher in broccoli compared to cauliflower and cabbage (Table 1). Thiocyanate concentrations were two to three orders of magnitude higher and nitrate concentrations were approximately five to six orders of magnitude higher than perchlorate.

Mean hypothetical perchlorate exposure for average individuals across age and gender was 1.6, 0.05, and $0.95 \mu \mathrm{g} /$ person for broccoli, cauliflower, and cabbage, respectively (Table 2). Estimated perchlorate exposures for cauliflower and cabbage are less than broccoli because concentrations are lower than broccoli, and the consumption of cauliflower and cabbage is less than broccoli.

Perchlorate in edible broccoli was used to estimate potential exposure and dosage across gender and age (Table 3). Even for broccoli, regardless of age and gender, the estimated dosages are less than $0.1 \%$ the reference dose of $0.7 \mu \mathrm{g} / \mathrm{kg}$ per day adopted by the USEPA (2005) on recommendation from the National Academy of Science (2005). This reference dose is based on a non-observed effect level (NOEL) of $7 \mu \mathrm{g} / \mathrm{kg}$ per day from a human perchlorate dosing study to which a tenfold uncertainty factor was applied to address potential sensitive subpopulations (Greer et al. 2002). Interestingly, these estimated perchlorate dosages for adults from broccoli were less than $13 \%$ of the 95th percentile of estimated total dosage of $0.234 \mu \mathrm{g} / \mathrm{kg}$ per day for the adult US population (Blount et al. 2006).

Another consideration with respect to the biological significance of perchlorate exposure is the presence of other natural goitrogens in food (Belzer et al. 2004). The iodine uptake inhibiting potential of a mixture of inhibitors can be forecast using perchlorate equivalent concentration (PEC). The PEC is defined as the sum of the concentrations of the inhibitors present divided by their inhibition potency 
Table 1 Range, mean, median, and 90th percentile levels of perchlorate, thiocyanate, and nitrate found in the edible portions of broccoli, cauliflower, and cabbage

\begin{tabular}{|c|c|c|c|c|c|c|}
\hline Crop & $\mathrm{n}$ & Min. & Max. & Mean & Median & 90th percentile \\
\hline \multicolumn{7}{|c|}{ Perchlorate $(\mu \mathrm{g} / \mathrm{kg}$ fw $)$} \\
\hline Broccoli & 55 & 3.5 & 106.9 & 23.8 & 19.3 & 37.2 \\
\hline Cauliflower & 38 & 4.2 & 40.7 & 12.8 & 11.2 & 23.7 \\
\hline Cabbage & 19 & 4.6 & 63.2 & 18.5 & 15.3 & 41.1 \\
\hline \multicolumn{7}{|c|}{ Thiocyanate $(\mu \mathrm{g} / \mathrm{kg} \mathrm{fw})$} \\
\hline Broccoli & 55 & 1965 & 56,219 & 17,917 & 15,030 & 36,664 \\
\hline Cauliflower & 38 & 1391 & 28,587 & 9,206 & 7,871 & 19,085 \\
\hline Cabbage & 19 & 1712 & 20,129 & 7,659 & 6,974 & 15,153 \\
\hline \multicolumn{7}{|c|}{ Nitrate $^{\mathrm{a}}(\mu \mathrm{g} / \mathrm{kg}$ fw $)$} \\
\hline Broccoli & 55 & 579,000 & $6,087,000$ & $1,717,000$ & $1,503,000$ & $3,174,000$ \\
\hline Cauliflower & 38 & 353,000 & $1,938,000$ & $1,037,000$ & 998,000 & $1,647,000$ \\
\hline Cabbage & 19 & 429,000 & $1,786,000$ & $1,001,000$ & $1,072,000$ & $1,458,000$ \\
\hline
\end{tabular}

${ }^{a}$ Rounded to $1,000 \mu \mathrm{g} / \mathrm{kg}$ fw

Table 2 Hypothetical exposures for members of the US population whom consume broccoli, cauliflower, and cabbage

\begin{tabular}{lll}
\hline Crop & $\begin{array}{l}\text { Consumption } \\
(\mathrm{g} / \text { day })\end{array}$ & $\begin{array}{l}\text { Perchlorate intake } \\
(\mu \mathrm{g} / \text { day })\end{array}$ \\
\hline Broccoli & $81(183)$ & $1.56(3.53)$ \\
Cauliflower & $4.7(13.1)$ & $0.05(0.15)$ \\
Cabbage & $62(149)$ & $0.95(2.28)$ \\
\hline
\end{tabular}

a All individuals age 2 and older

b Values in parenthesis are 90th percentile values. Intake ( $\mu \mathrm{g}$ perchlorate/day $)=$ concentration $(\mu \mathrm{g} / \mathrm{kg}$ fresh weight $) \times$ consumption (kg/day)

relative to perchlorate on a weight ingestion basis. Recent work has shown that the relative potency of perchlorate to inhibit iodide uptake at the NIS was 15 times that of thiocyanate and 240 times that of nitrate (Tonacchera et al. 2005). However, because thiocyanate has a serum half-life 18-29 times that of perchlorate and nitrate, the corresponding relative potencies on an ingested-weight basis were calculated 0.5 and 240 for thiocyanate and nitrate, respectively. Thus, the PEC of a food containing perchlorate, thiocyanate, and nitrate can be estimated as the concentration of perchlorate plus $1 / 0.5 \times$ thiocyanate and $1 /$ $240 \times$ of the concentration of nitrate.

Table 4 shows the PEC calculated using the average concentrations of perchlorate, thiocyanate, and nitrate in the Brassica sp. samples collected. The iodine uptake inhibition potential from perchlorate is less than $0.1 \%$ that estimated from all measured iodide uptake inhibitors combined. There is uncertainty about how thiocyanates are extracted from plant residues using our methodology relate

Table 3 Hypothetical mean and 90th percentile exposure of children and adults whom consume broccoli produced in the lower Colorado River region

\begin{tabular}{llllll}
\hline Gender & $\begin{array}{l}\text { Age } \\
\text { (years })\end{array}$ & $\begin{array}{l}\text { Body } \\
\text { weight }(\mathrm{kg})\end{array}$ & $\begin{array}{l}\text { Consumption }^{\mathrm{a}} \\
(\mathrm{g} / \text { day })\end{array}$ & $\begin{array}{l}\text { Intake }^{\mathrm{a}, \mathrm{b}} \\
(\mu \mathrm{g} / \text { day })\end{array}$ & $\begin{array}{l}\text { Dosage } \\
\text { weight day })^{\mathrm{a}}(\mathrm{kg} \text { body }\end{array}$ \\
\hline Males and females & $2-5$ & 16 & $49(92)$ & $0.95(1.78)$ & $0.06(0.11)$ \\
Males and females & $6-11$ & 29 & $67(177)$ & $1.29(3.42)$ & $0.04(0.12)$ \\
Males & $12-19$ & 58 & $82(182)$ & $1.58(3.51)$ & $0.03(0.06)$ \\
Females & $12-19$ & 53 & $82(183)$ & $1.58(3.53)$ & $0.03(0.06)$ \\
Males & $20-39$ & 77 & $114(233)$ & $2.20(4.50)$ & $0.03(0.06)$ \\
Females & $20-39$ & 61 & $77(159)$ & $1.49(3.07)$ & $0.02(0.05)$ \\
Males & $40-59$ & 78 & $90(183)$ & $1.74(3.53)$ & $0.02(0.05)$ \\
Females & $40-59$ & 65 & $65(154)$ & $1.25(2.97)$ & $0.02(0.05)$ \\
Males & $>60$ & 74 & $82(183)$ & $1.58(3.53)$ & $0.02(0.05)$ \\
Females & $>60$ & 65 & $78(155)$ & $1.51(2.99)$ & $0.02(0.05)$ \\
\hline
\end{tabular}

${ }^{\text {a }}$ Values in parenthesis are 90th percentile values

${ }^{\mathrm{b}}$ Exposure estimates were made using consumption data sets (Smiciklas-Wright et al. 2002) and body weights factors (USEPA 1998) compiled by others. Dosage $(\mu \mathrm{g} / \mathrm{kg}$ body weight $)=$ exposure $(\mu \mathrm{g} / \mathrm{day}) /$ body weight $(\mathrm{kg})$ 
Table 4 The perchlorate equivalent concentrations (PECs) of anions in broccoli, cauliflower, and cabbage produced in the lower Colorado River region

\begin{tabular}{lllll}
\hline Crop & $\begin{array}{l}\text { Perchlorate } \\
(\mu \mathrm{g} / \mathrm{kg} \mathrm{fw})\end{array}$ & $\begin{array}{l}\text { PEC of } \\
\text { thiocyanate } \\
(\mu \mathrm{g} / \mathrm{kg} \mathrm{fw})\end{array}$ & $\begin{array}{l}\text { PEC nitrate } \\
(\mu \mathrm{g} / \mathrm{kg} \mathrm{fw})\end{array}$ & $\begin{array}{l}\text { Total PEC }^{\mathrm{a}} \\
(\mu \mathrm{g} / \mathrm{kg})\end{array}$ \\
\hline Broccoli & 19.3 & 30,060 & 6,263 & 36,342 \\
Cauliflower & 11.2 & 15,742 & 4,158 & 19,912 \\
Cabbage & 15.3 & 13,948 & 4,467 & 18,429 \\
\hline
\end{tabular}

${ }^{\mathrm{a}}$ Total PEC $=\left(\mathrm{ClO}_{4}\right)+($ thiocyanate $\left.) / 0.5\right)+($ nitrate $/ 240)$

to that released upon ingestion. Studies with animals and humans have shown serum and urine thiocyanate levels increase with consumption of Brassica sp. (Cox-Ganser et al. 1994; Olea and Parras 1992; Tripathi et al. 2001). Therefore, even if our extraction procedure over-estimated the thiocyanate released upon ingestion by two orders of magnitude, the thiocyanate and nitrate would be more likely to inhibit NIS than the perchlorate found in these Brassica species. This observation is consistent with previous observations we have made with nitrate and perchlorate in lettuce (Lactuca sativa L.) and underscore the paradox of assigning risk to the trace levels of perchlorate associated with consumption of food crops produced in the lower Colorado River region (Sanchez et al. 2005b).

In conclusion, Brassica sp. irrigated with Colorado River water do accumulate trace levels of perchlorate. However, the levels of perchlorate observed are low relative to the nitrate and thiocyanate naturally present in these food plants and low relative to the reference dose recommended by the NAS and the USEPA.

Acknowledgments Funding for this study was provided by a grant from USDA National Integrated Food Safety Program. We are also grateful to the producers in the lower Colorado River region, who allowed us access to their production fields.

Disclaimer The findings and conclusions in this report are those of the authors and do not necessarily represent the views of the Centers for Disease Control and Prevention.

\section{References}

Baker AS, Smith R (1969) Extracting solution for potentiometric determination of nitrate in plant tissue. J Agric Food Chem 17:1284-1287

Belzer RB, Bruce GM, Peterson MK, Pleus RC (2004) Using comparative exposure analysis to validate - low-dose human health risk assessment: the case of perchlorate. In: Linkov I, Ramadan A (eds). Comparative risk assessment and environmental decision making. Kluwer, New York
Blount BC, Valentin-Blasini L, Osterloh JD, Mauldin JP, Pirkle JL (2007) Perchlorate exposure of the US population, 2001-2002. J Expo Sci Environ Epidemiol 17(4):400-407

Clark JJ (2000) Perchlorate toxicology, chap 3. In: Urbansky ET (ed) Perchlorate in the environment. Kluwer/Plenum, New York

Cox-Ganser JM, Jung GA, Pushkin PT, Reid RL (1994) Evaluation of Brassica in grazing system for sheep II. Blood composition and nutrient status. J Anim Sci 72:1832-1841

DHS (2000) Standards for perchlorate in drinking water. Department of Health Services, Sacramento, CA, USA. http://www.dhs. cahwnet.gov/org/ps/

Ellington JJ, Evans JJ (2000) Determination of perchlorate at partsper-billion levels in plants by ion chromatography. J Chromatogr A 898:193-199

Greer MA, Goodman G, Pleus RC, Greer SE (2002) Health effects for environmental perchlorate contamination: the dose response for inhibition of radioiodide uptake in humans. Environ Health Perspect 110:927-937

Jackson WA, Joseph P, Laxman P, Tan K, Smith PN, Yu L, Anderson TA (2005) Perchlorate accumulation in forage and edible vegetation. J Agric Food Chem 53:369-373

Kushad MM, Brown AF, Kurilich AC, Juvick JA, Klein BP, Wallig MA, Jeffery EH (1999) Variation of glucosinolates in vegetable crops of Brassica oleracea. J Agric Food Chem 47:1541-1548

National Academy of Science (2005) Health implications of perchlorate ingestion. National Research Council of the National Academies Press, Washington, DC

Olea F, Parras P (1992) Determination of serum levels of dietary thiocyanate. J Anal Toxic 16:258-260

Sanchez CA, Crump KS, Krieger RI, Khandaker NR, Gibbs JP (2005a) Perchlorate and nitrate in leafy vegetables of North America. Environ Sci Technol 39:9391-9397

Sanchez CA, Krieger RI, Khandaker RN, Moore RC, Holts KC, Neidel LL (2005b) Accumulation and perchlorate exposure potential of lettuce produced in the lower Colorado River region. J Agric Food Chem 53:5479-5486

Sanchez CA, Krieger RI, Khandaker NR, Valentin-Blasini L, Blount BC (2006) Potential perchlorate exposure from Citrus sp. irrigated with contaminated water. Anal Chim Acta 567:33-38

Smiciklas-Wright H, Mitchell DC, Mickle SJ, Cook AJ, Goldman JD (2002) Foods commonly eaten in the United States. Quantities consumed per eating occasion and in a day, 1994-1996. USDA NFS Report No. 96-5

Tan K, Anderson TA, Jones MW, Smith PN, Jackson WA (2004) Accumulation of perchlorate in aquatic and terrestrial plants on a field scale. J Environ Qual 33:1638-1646

Tonacchera M, Pinchera A, Dimida A, Ferrarini E, Agretti P, Vitti P, Santini F, Crump K, Gibbs J (2005) Relative potencies and additivity of perchlorate, thiocyanate, nitrate, and iodide on the inhibition of radioactive iodide uptake at the sodium iodide symporter. Thyroid 14:1012-1019

Tripathi MK, Mishra AS, Mondal D, Karim SA (2001) Effects of substitution of groundnut with high glucosinilate mustard (Brassica juncea) meal on nutrient utilization, growth, vital organ weight, and blood composition of lambs. Small Rumin Res 39(3):261-267

USEPA (2005) Reference dose for chronic oral exposure. http://www.epa.gov/iris/subst/1007.htm

USEPA (1998) Exposure factors handbook. In: General factors, vol 1. Office of Research and development, National Center for Environmental Assessment. Washington, DC

Valentin-Blasini L, Mauldin JP, Maple D, Blount BC (2005) Analysis of perchlorate in human urine using ion chromatography and electrospray tandem mass spectroscopy. Anal Chem 77:24752481 
Wyngaarden JB, Stanbury JB, Rapp B (1953) The effects of iodide, perchlorate, thiocyanate, and nitrate administration upon the iodide concentrating mechanism of the rat thyroid. Endocrinology 52:568-574
Yu Lu, Canas JE, Cobb GP, Jackson WA, Anderson TA (2004) Uptake of perchlorate in terrestrial plants. Ecotox Env Safety 58:44-49 